Publisher homepage: www.universepg.com, ISSN: 2663-6913 (Online) \& 2663-6905

(Print) https://doi.org/10.34104/ajpab.019.0192029

\title{
Assessment and Biomonitoring of the Effect of Rapeseeds Oil on Wister Rat Organs
}

\author{
Imdadul Haque Sharif ${ }^{1}$, Saheda Tamanna ${ }^{2}$, Md. Golam Mosaib ${ }^{3}$, Nasrin Tamanna ${ }^{1}$, Md. Anwarul \\ Haque $^{1}$, Md. Abu Hena Mostofa Jamal ${ }^{1}$, and Md Ekhlas Uddin ${ }^{3}$
}

${ }^{1}$ Dept. of Biotechnology and Genetic Engineering, Islamic University, Bangladesh; ${ }^{2}$ Dept. of Biotechnology and Genetic Engineering, Noakhali Science and Technology University, Bangladesh; and ${ }^{3}$ Dept. of Biochemistry and Molecular Biology, Gono Bishwabidyalay, Bangladesh.

*Correspondence: sharifbtge07@gmail.com

\begin{abstract}
Rapeseed oil is one of the important and cheapest vegetables oil in Bangladesh and many other countries. It is commonly used as cooking oil in Bangladesh particularly in rural areas and also used as other food items. This study evaluated the physiological effects of four type's rapeseeds namely Mustard (Wild), Mustard (hybrid), Rai (Wild), Rai (hybrid) oil on six strains of bacteria in addition to studying the effects of two varieties of rapeseeds oil Mustard (Wild) and Rai (hybrid) oil on Wistar rat's organs including liver, kidney, heart and skeletal muscles. Firstly, we examined the effects of these Rapeseeds oil on bacteria and found that these Rapeseeds oil possess antibacterial activities. Six bacterial strains such as B. subtilis, S. lutea, X. campestris, E. coli, K. Pneumonia, P. denitrificans was used to test the effect of these rapeseeds oil and observed that rapeseed oil showed inhibition against tested microorganisms in concentration-dependent manner. Finally, the effects of oil obtained from these two varieties were investigated after feeding rats for 8 weeks. Male Wistar rats were divided into three groups, each group contains 4 rats. Group A was considered as control diet group, while Group B was mustard (Wild) oil group and Group C was Rai (hybrid) oil group. Group A was containing 0.6 gram oil plus $14.4 \mathrm{gm}$ diet. We found that rats of both experimental groups exhibit weight loss, reduction of food efficiency ratio and increase cardiac and hepatic enzymes including CK-MB, ALP, SGPT and SGOT compared to the rats fed controlled diet. Furthermore, we also found that the bodyweight loss, food efficiency ratio markedly decreased and tested enzymes increased in rats fed Mustard (Wild) oil compared to rat fed Rai (hybrid) oil.
\end{abstract}

Keyword: Rapeseed, Erucic acid, Food efficiency ratio, Vegetable oil, Brassica spp, and Wister rat organs.

\section{INTRODUCTION}

Rapeseed is commonly known as mustered, Brassica spp in Bangladesh, is an annual, winter season crop a native to temperature regions of Europe (Bhuiyan et al., 2008). Rape is a Latin word means turnip and rapeseed belong to the family Cruciferae is an important oil crop and currently it is the principal oil crop of Bangladesh. It contains 40-45\% oil and 2025\% protein in seed (Mosyakin, 1996; Sarker et al., 2019). Beneficial health effects also arise from the content of phenolic compounds, which are known to exert antimutagenic, anti-inflammatory activities (Cao et al., 2008; Vuorela et al., 2005). The antioxidant potential of phenolic compounds from rapeseed oil has been reported in the literature (Thiyam et al., 2006; Wakamatsu et al., 2005). This oil is a major source of vegetable oil in the world and contains many active biological compounds such as phytosterols, tocopherol, phenolics, $\beta$-carotene (Siger, 2017).

In Bangladesh, rapeseed and mustard are major sources of edible oils and are mostly grown on the residual soil moisture in Rabi season. Many different 
parts of plants may yield oil in actual commercial practice oil is extracted primarily from the seeds of oilseed plants. Vegetable fats and oils are not only edible but also non-edible such as processed linseed oil and castor oil used in lubricants, paints, cosmetics, pharmaceuticals, and other industrial purposes. This fats and oils are used to describe concentrated energy sources found in many foods. Without fats and oils, our bodies would not function properly. The oil Rapeseed is one of the most valuable vegetable fats, due to its nutritional properties. It is a rich source of mono- and polyunsaturated fatty acids, while saturated fatty acids are minor constituents (Gunstone, 2011). The rapeseed oil extracted from the rapeseed top-quality edible oil, which contains rich acids, fast-soluble vitamins, phospholipids, and pigments but lacks cholesterol (Martin Hernandez, 2008). It also contains highquality oil (38-46\%) and protein (20-30\%) as well as some antinutritional compounds, such as glucosinolates, phenols, and phytic acid (Zhang, 2007). Rapeseed processing in the food and chemical industry results in some by-products which can be used as animal feeds or as a protein component of the diet (Lomascolo et al., 2012).

Vegetables fats and oils are derived from plants that are composed of mainly triglycerides. Rapeseed oil contains high levels of erucic acid that is damaging to the cardiac muscle of animals, and made it less nutritious in animal feed (O'brien, 2008). It helps to stay away from coronary heart disease and provide energy and transport fat-soluble vitamins A, D, E, and K. It also provides the essential fatty acids omega 3, 6 and 9 involved in many important functions in the body, including heart health. Help keep us warm and protect internal organs like the kidneys contain plant sterols (McKevith, 2005). However, the particular role of the component of these rapeseeds oil remains yet to be studied (O'brien, 2008). Therefore, the present study was undertaken with the aims and objectives is to determine the antimicrobial activities of these rapeseeds oil against some test pathogens to determine the body weight gain (growth rate) of rats fed with both oil supplements, to measure the amount of food consumed by rats, to calculate Food Efficiency Ratio (FER) of rats fed with rapeseeds oil, and to investigate the adverse condition of rats heart and liver by measuring the biomarker SGOT (AST), SGPT (ALT), CK-MB and ALP.

\section{MATERIALS AND METHODS}

2.1 Collection of Seeds - At first fresh, healthy and good quality Mustard (hybrid) seeds collected from BADC Amjhupi, Maherpur and Rai (hybrid) seeds collected from the farmers of "Shehala" Village, Daulatpur, Kushtia. Then the seeds were stored at $4^{\circ} \mathrm{C}$ in the refrigerator with the sealed plastic packet to avoid the microbial contamination.

2.2 Preparation and Storage of Oil - To preparation of the experimental oil, stored seeds were taken out from the refrigerator to the ghanni mil at Sheikhpara, Jhenidah. The bottle was also stored at $-28^{\circ} \mathrm{C}$ to prevent photo-oxidation. The bottle was preserved in a dark, cool and dry place.

\subsection{Media}

2.3.1 Nutrient Broth Media - The Nutrient broth is typically made of a powder beef or yeast extract that contains peptones (broken down proteins). The powder is dissolved in water, put in the conical flask and sterilized and incubated for 24 hours or more to encourage bacterial growth.

2.3.2 Nutrient Agar Media - Nutrient agar medium used for the cultivation of microbes supporting the growth of a wide range of non-fastidious organisms.

2.4 Sample Used - Sample used for this purpose are four types of rapeseed oil. Oil samples are Mustard (wild) oil, Mustard (hybrid) oil, Rai (wild) oil, Rai (hybrid) oil. Oil directly extracted from seeds from an oil mill in a local market. Seeds are collected from farmers and local market in Kushtia, a general town in Bangladesh.

\subsection{Preparation of Pure Culture and Sample} Inoculation - To determine anti-microbial activity of oils, we had to prepare media for bacterial growth. Our experiment is divided into two parts. The first part includes the preparation of pure culture of each bacterial strain and the second part includes the spread of microbes in an agar plate and inoculate sample.

2.6 Disk Preparation - Make disks to soak sample oil by filter paper in the desired size. Take all disks in a bicker. Seal the bicker with aluminum foil paper to avoid contamination. Then sterilize the disk in the autoclave at $121{ }^{\circ} \mathrm{C}$ for $30 \mathrm{~min}$ and open the bicker in front of laminar airflow. 


\subsection{Animal Care and Treatment}

2.7.1 Experimental Animals (Wistar rat) - A rat of the species Rattus norvegicus which is bred and kept for scientific research is being used in the laboratory.

2.7.2 Animal Maintenance - Adult healthy male Wistar rats were purchased from animal house, Dept. of Pharmacy, Jahangirnagar University, Savar, Dhaka. With an average weight of about $80-100 \mathrm{gm}$ (4 weeks of rat). The rats were housed in a wooden cage with steel wire tops and wood-cob bedding (4 rats per cage) and had access to food and water at the BTGE laboratory.

2.7.3 Diet and Dosing of Oil - At first, the rats were adapted for five days. They were fed standard diet. The standard diet was purchased from animal house, Jahangirnagar University, Dhaka, Bangladesh. The a standard diet consisted of $7 \%$ protein source, $20 \%$ rice polish, $30 \%$ wheat bran and flour, $1.5 \%$ soybean oil and common salt, $0.5 \%$ vitamin mixture and $2.5 \%$ molasses. Each rat was fed about $15 \mathrm{gm}$ of diet/day. The appropriate doses of rapeseeds oil and diet given to the rats were carefully weighed using the electrical balance. Feeding was continued for 8 weeks. Amount of food consumed and the individual bodyweight of the rats of group A, B and C ware $89.33,83.25$ and $86.75 \mathrm{~g}$ respectively.

\subsubsection{Calculation of Food Efficiency Ratio (FER) -}

During the study, the weight of each rat was measured every day using the balance. The food efficiency ratio for each rat was calculated using the following formula: FER=Body weight gain/Food consume.

\subsubsection{Sample Collection and Preservation - After 56} days of feeding, the 14 hours fasted rats were subjected to light anesthesia using chloroform. At first, the abdomen was washed using ethanol to avoid contamination. With the use of scissors and wearing gloves the abdomen was opened, blood samples were collected with $3 \mathrm{ml}$ syringe from abdominal aorta or heart. Then the blood sample was transferred into a $1.5 \mathrm{ml}$ Eppendrof tube. For coagulation, blood was kept about 10 minutes at room temperature. After centrifugation at 3000 r.p.m for 15 minutes at $4{ }^{\circ} \mathrm{C}$ using Thermo scientific centrifuge, then the serum was carefully drawn off and placed in a $1.5 \mathrm{ml}$ Eppendrof tube and preserved at $-80{ }^{\circ} \mathrm{C}$ until the experiments were performed. Various organs namely heart, liver, kidney, tail, adipose tissue and skeletal muscle were collected, put onto Petridis and washed in $0.9 \%$ saline and then preserved. Heart sample was collected and preserved in Bouins Fluid. The liver, kidney, tail, adipose tissue and skeletal muscle were preserved in formaldehyde for further investigation. Bouins fluid contains $71.43 \%$ saturated picric acid, $4.76 \%$ glacial acetic acid, and $23.81 \%$ formaldehyde, which is known as a strong preservative.

\subsection{Biochemical Analysis of Serum}

\subsubsection{Determination of Serum Glutamate Oxalo-} acetate Transaminase SGOT (AST) and Serum Glutamate Pyruvate Transaminase (SGPT) - SGOT and SGPT also have known as aspartate aminotransferase (AST) and alanine amino transferase (ALT), respectively. For the analysis of blood serum SGOT (AST) and SGPT (ALT) is used as a biomarker. Commercially available kits were used for the determination of SGOT and SGPT level in blood serum according to the Optimized UV-Test (Walter et al 1991). For the determination of SGOT and SGPT enzyme reagent (R1) and substrate liquid buffer (R2) were supplied ready-to-use. Prepared working reagent in the ratio of 4 parts enzyme reagent (R1) to 1 part substrate (R2).

At first, we were taken zero spectrophotometers at 340 nm with distilled water. For each sample and control, $200 \mu 1$ serum sample added with $1000 \mu$ mono reagent $(\mathrm{R} 1+\mathrm{R} 2)$. Gently mixed and absorbance was recorded after 1 minute at $25^{\circ} \mathrm{C}$. Incubation continued at $25^{\circ} \mathrm{C}$ and absorbance were recorded again at 2 and 3 minutes. Determined the average absorbance per minute $(\Delta \mathrm{A} / \mathrm{min})$ and multiplied by the factor 952 for results in $\mathrm{U} / \mathrm{L}$.

\subsubsection{Determination of Alkaline Phosphatase (ALP)-} Kits were used in the determination of alkaline phosphatase according to the Optimized Standard Method (Weber et al., 1998). For the determination of ALP, alkaline phosphatase buffer and substrate liquid buffer were ready to use. Prepare working reagent in the ratio of 4 parts Buffer (R1) to 1 part Enzyme (R2) (i.e. $24 \mathrm{ml}$ Buffer and $6 \mathrm{ml}$ Substrate). At first, we were taken zero spectrophotometers at $405 \mathrm{~nm}$ with distilled water. For each sample and control, $20 \mu 1$ serum sample added with $1000 \mu \mathrm{l}$ mono reagent $(\mathrm{R} 1+\mathrm{R} 2)$. Gently mixed and absorbance was recorded after1minute at $37^{\circ}$ C. Incubation continued at $37^{\circ} \mathrm{C}$ and absorbance's were recorded again at 2 and 3 minutes. Then determined the average absorbance per minute $(\Delta \mathrm{A} / \mathrm{min})$ and multiplied by the factor 2757 for results in U/L. 


\subsubsection{Determination of Creatine Kinase (CK-MB) -}

For the quantitative determination of Creatine KinaseMB in serum manual procedure was used. The procedures given by the manufacturers were followed without any modifications for the determination of these parameters. For the quantitative determination of Creatine Kinase MB (CK-MB) liquid buffer (R1) and enzyme (R2) liquid reagents are supplied readyto-use. Prepare working reagent in the ratio of 4 parts Buffer (R1) to 1 part Enzyme (R2). At first, we were taken zero spectrophotometers at $340 \mathrm{~nm}$ with distilled water. For each sample and control, $1.0 \mathrm{ml}$ working reagent added to cuvet and warmed to $37^{\circ}$ for 4 minutes. Added $40 \mu 1$ of serum to its respective tube and mixed gently. Incubation continued at $37^{\circ} \mathrm{C}$ and absorbance were recorded again at 6, 7, 8 and 9 minutes. Then determined the average absorbance per minute $(\Delta \mathrm{A} / \mathrm{min})$ and multiplied by the factor 8360 for results in $\mathrm{U} / \mathrm{L}$.

\section{RESULTS AND OBSRVATION}

\subsection{Effects of Four Varieties of Oil on Micro-} organisms.

3.1.1 Effects of Mustard (wild) Oil on Xanthomonas campestris - The experiment show that Mustard (Wild) oil plays a significantly inhibitory effect on $X$. campestris at the concentration of $1.5 \mu 1 /$ disk compared to control plate.
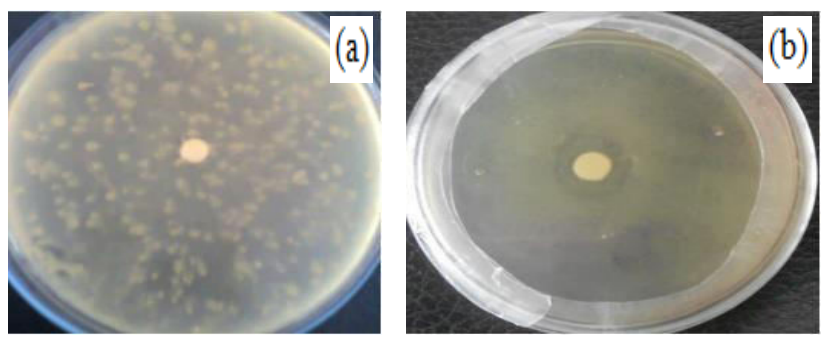

Fig 1: (a) Control plate of strain 004 (X. campestris); (b) Highest inhibition of microbial growth at $1.5 \mu 1$.

\subsubsection{Effects of Mustard (Hybrid) Oil on Klebsiella} pneumonia - The experiment also shows that Mustard (hybrid) oil significantly inhibits $K$. pneumonia at the concentration of $1.5 \mu \mathrm{l} / \mathrm{disk}$ compared to the control plate
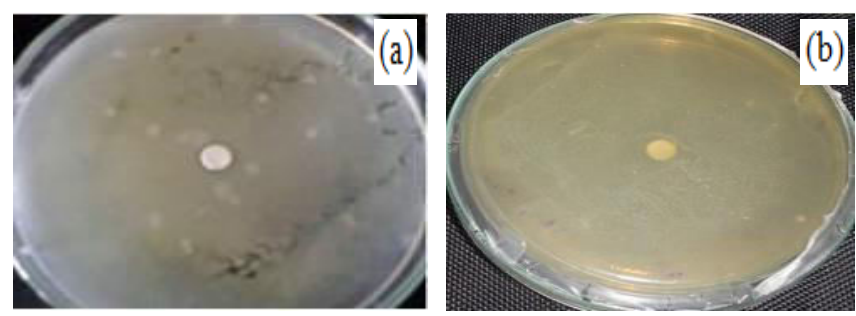

Fig 2: (a) Control plate of $K$. pneumonia; (b) Highest inhibition of microbial growth at $1.5 \mu$ l.

3.1.3 Effects of Rai (Wild) Oil on Sarcina lutea - The experiment also show that Rai (wild) oil significantly inhibits $S$. lutea at the concetration of $1.5 \mu \mathrm{l} / \mathrm{disk}$ compared to the control plate.
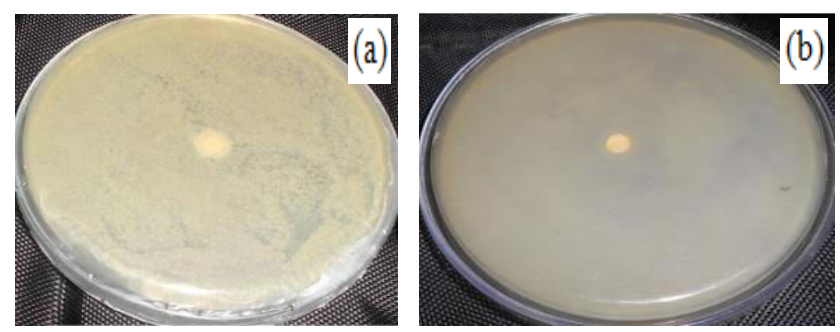

Fig 3: (a) Control plate of strain 002 (S. lutea); (b) Highest inhibition of microbial growth at $1.5 \mu 1$.

\subsubsection{Effects of Rai (Hybrid) Oil on Pseudomonas} denitrificans - The experiment also show that Rai (hybrid) oil significantly inhibits $P$. denitrificans at the concentration of $2 \mu \mathrm{l} /$ disk compared to control plate.
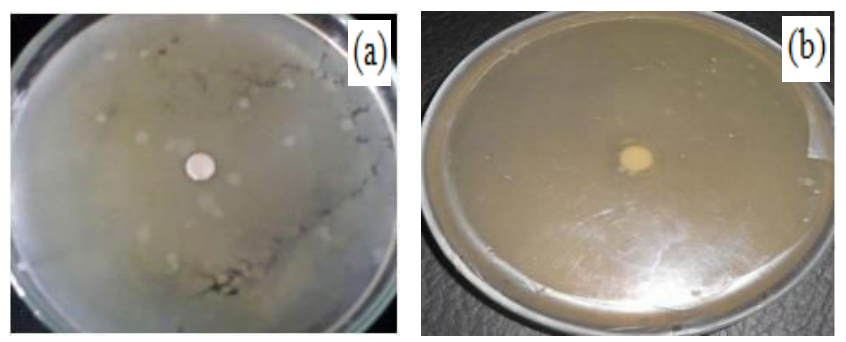

Fig 4: (a) Control plate of strain 010 ( $P$. denitrificans), and (b) Highest inhibition of microbial growth at $2 \mu 1$.

Table 1: Effects of four types of rapeseeds oil on microorganisms.

\begin{tabular}{|c|c|c|c|c|c|c|}
\hline $\begin{array}{c}\text { Serial } \\
\text { No }\end{array}$ & $\begin{array}{c}\text { Bacterial } \\
\text { strains }\end{array}$ & $\begin{array}{c}\text { Result of } \\
\text { control (Disks } \\
\text { without oil) }\end{array}$ & $\begin{array}{l}\text { Amount of } \\
\text { oil- 0.5 } \mu \text { l } \\
\text { Shows }\end{array}$ & $\begin{array}{c}\text { Amount of oil- } \\
1.0 \mu l \text { Shows }\end{array}$ & $\begin{array}{l}\text { Amount of } \\
\text { oil- } 1.5 \mu \mathrm{l} \\
\text { Shows }\end{array}$ & $\begin{array}{c}\text { Amount of oil- } \\
2.0 \mu \mathrm{l} \text { Shows }\end{array}$ \\
\hline 1. & $\begin{array}{c}\text { 001(Bacillus } \\
\text { subtilis) }\end{array}$ & $\begin{array}{c}\text { Positive } \\
\text { growth }\end{array}$ & $\begin{array}{l}\text { moderate } \\
\text { inhibition }\end{array}$ & $\begin{array}{c}\text { more inhibition } \\
\text { than amount of } \\
0.5 \mu 1 .\end{array}$ & $\begin{array}{c}\text { greater } \\
\text { inhibition } \\
\text { than amount } \\
\text { of } 1.0 \mu \mathrm{l}\end{array}$ & $\begin{array}{c}\text { greatest } \\
\text { inhibition among } \\
\text { the } 4 \text { types of oil } \\
\text { concentration }\end{array}$ \\
\hline
\end{tabular}




\begin{tabular}{|c|c|c|c|c|c|c|}
\hline 2. & $\begin{array}{c}002 \text { (Sarcina } \\
\text { lutea) }\end{array}$ & $\begin{array}{l}\text { Positive } \\
\text { growth }\end{array}$ & $\begin{array}{c}\text { less } \\
\text { inhibition }\end{array}$ & mild inhibition & $\begin{array}{c}\text { high } \\
\text { inhibition }\end{array}$ & high inhibition. \\
\hline 3. & $\begin{array}{c}004 \\
\text { (Xanthomonas } \\
\text { campestris) }\end{array}$ & $\begin{array}{l}\text { Positive } \\
\text { growth }\end{array}$ & $\begin{array}{c}\text { mild } \\
\text { inhibition }\end{array}$ & $\begin{array}{l}\text { moderate } \\
\text { inhibition }\end{array}$ & $\begin{array}{c}\text { high } \\
\text { inhibition. }\end{array}$ & high inhibition. \\
\hline 4. & $\begin{array}{c}005 \text { (E. coli } \\
\text { iw 3310) }\end{array}$ & $\begin{array}{l}\text { Positive } \\
\text { growth }\end{array}$ & $\begin{array}{c}\text { less } \\
\text { inhibition }\end{array}$ & mild inhibition & $\begin{array}{c}\text { high } \\
\text { inhibition }\end{array}$ & high inhibition \\
\hline 5. & $\begin{array}{c}006 \\
\text { (Klebsiella } \\
\text { pneumonia) }\end{array}$ & $\begin{array}{c}\text { Positive } \\
\text { growth }\end{array}$ & $\begin{array}{c}\text { mild } \\
\text { inhibition }\end{array}$ & $\begin{array}{l}\text { mild inhibition } \\
\text { but greater than } \\
\text { amount of } 0.5 \mu 1 .\end{array}$ & $\begin{array}{c}\text { high } \\
\text { inhibition }\end{array}$ & high inhibition \\
\hline 6. & $\begin{array}{c}010 \\
\text { (Pseudomonas } \\
\text { denitrificans) }\end{array}$ & $\begin{array}{c}\text { Positive } \\
\text { growth }\end{array}$ & $\begin{array}{c}\text { mild } \\
\text { inhibition }\end{array}$ & high inhibition & $\begin{array}{c}\text { high } \\
\text { inhibition }\end{array}$ & $\begin{array}{c}\text { greater } \\
\text { inhibition }\end{array}$ \\
\hline
\end{tabular}

Table 2: Mustard oil (hybrid type seeds).

\begin{tabular}{|c|c|c|c|c|c|c|}
\hline $\begin{array}{c}\text { Serial } \\
\text { No }\end{array}$ & $\begin{array}{c}\text { Bacterial } \\
\text { strains }\end{array}$ & $\begin{array}{c}\text { Result of } \\
\text { control (Disks } \\
\text { without oil) }\end{array}$ & $\begin{array}{l}\text { Amount of } \\
\text { oil- } 0.5 \mu \text { l } \\
\text { Shows }\end{array}$ & $\begin{array}{c}\text { Amount of oil- 1.0 } \mu \text { l } \\
\text { Shows }\end{array}$ & $\begin{array}{l}\text { Amount of } \\
\text { oil- } 1.5 \mu \mathrm{\mu l} \\
\text { Shows }\end{array}$ & $\begin{array}{l}\text { Amount of oil- } \\
2.0 \mu \text { l Shows }\end{array}$ \\
\hline 1. & $\begin{array}{c}001 \text { (Bacillus } \\
\text { subtilis) }\end{array}$ & $\begin{array}{l}\text { Positive } \\
\text { growth }\end{array}$ & $\begin{array}{c}\text { less } \\
\text { inhibition }\end{array}$ & mild inhibition & $\begin{array}{c}\text { high } \\
\text { inhibition }\end{array}$ & high inhibition \\
\hline 2. & $\begin{array}{c}002 \text { (Sarcina } \\
\text { lutea) }\end{array}$ & $\begin{array}{l}\text { Positive } \\
\text { growth }\end{array}$ & $\begin{array}{c}\text { less } \\
\text { inhibition }\end{array}$ & mild inhibition & $\begin{array}{l}\text { moderate } \\
\text { inhibition }\end{array}$ & $\begin{array}{l}\text { moderate } \\
\text { inhibition }\end{array}$ \\
\hline 3. & $\begin{array}{c}004 \\
\text { (Xanthomonas } \\
\text { campestris) } \\
\end{array}$ & $\begin{array}{l}\text { Positive } \\
\text { growth }\end{array}$ & $\begin{array}{c}\text { mild } \\
\text { inhibition }\end{array}$ & $\begin{array}{l}\text { moderate inhibition } \\
\text { but more than the } \\
\text { amount of } 0.5 \mu l \text {. }\end{array}$ & $\begin{array}{c}\text { high } \\
\text { inhibition }\end{array}$ & high inhibition \\
\hline 4. & $\begin{array}{l}005(\text { E. coli } \\
\text { iw 3310) }\end{array}$ & $\begin{array}{l}\text { Positive } \\
\text { growth }\end{array}$ & $\begin{array}{l}\text { moderate } \\
\text { inhibition }\end{array}$ & $\begin{array}{l}\text { more inhibition but } \\
\text { more than of } 0.5 \mu 1 .\end{array}$ & $\begin{array}{c}\text { high } \\
\text { inhibition }\end{array}$ & high inhibition \\
\hline 5. & $\begin{array}{c}006 \\
\text { (Klebsiella } \\
\text { pneumonia) }\end{array}$ & $\begin{array}{l}\text { Positive } \\
\text { growth }\end{array}$ & $\begin{array}{l}\text { moderate } \\
\text { inhibition }\end{array}$ & $\begin{array}{l}\text { more inhibition than } \\
\text { the amount of } 0.5 \mu 1 .\end{array}$ & $\begin{array}{l}\text { higher } \\
\text { inhibition }\end{array}$ & $\begin{array}{c}\text { higher inhibition } \\
\text { among the } 4 \\
\text { concentrations of } \\
\text { oil } \\
\end{array}$ \\
\hline 6. & $\begin{array}{c}010 \\
\text { (Pseudomonas } \\
\text { denitrificans) }\end{array}$ & $\begin{array}{l}\text { Positive } \\
\text { growth }\end{array}$ & $\begin{array}{c}\text { less } \\
\text { inhibition }\end{array}$ & mild inhibition & $\begin{array}{l}\text { high } \\
\text { inhibition }\end{array}$ & high inhibition \\
\hline
\end{tabular}

Table 3: Rai Oil (hybrid type seeds).

\begin{tabular}{|c|c|c|c|c|c|c|}
\hline \begin{tabular}{|c|} 
Serial \\
No
\end{tabular} & $\begin{array}{c}\text { Bacterial } \\
\text { strains }\end{array}$ & $\begin{array}{c}\text { Result of } \\
\text { control (Disks } \\
\text { without oil) } \\
\end{array}$ & 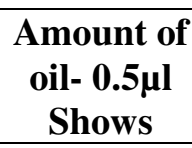 & $\begin{array}{l}\text { Amount of oil- } \\
\text { 1.0ul Shows }\end{array}$ & $\begin{array}{c}\text { Amount of oil- } \\
1.5 \mu l \text { Shows }\end{array}$ & $\begin{array}{c}\text { Amount of oil- } \\
2.0 \mu l \text { Shows }\end{array}$ \\
\hline 1. & $\begin{array}{l}001 \text { (Bacillus } \\
\text { subtilis) }\end{array}$ & Positive growth & $\begin{array}{l}\text { moderate } \\
\text { inhibition }\end{array}$ & high inhibition & high inhibition & high inhibition \\
\hline 2. & $\begin{array}{c}002 \text { (Sarcina } \\
\text { lutea) }\end{array}$ & Positive growth & $\begin{array}{c}\text { mild } \\
\text { inhibition }\end{array}$ & mild inhibition & $\begin{array}{l}\text { moderate } \\
\text { inhibition }\end{array}$ & high inhibition \\
\hline 3. & $\begin{array}{c}004 \\
\text { (Xanthomonas } \\
\text { campestris) }\end{array}$ & Positive growth & $\begin{array}{l}\text { less } \\
\text { inhibition }\end{array}$ & mild inhibition & mild inhibition & mild inhibition \\
\hline 4. & $\begin{array}{c}005 \text { (E. coli iw } \\
3310)\end{array}$ & Positive growth & $\begin{array}{l}\text { moderate } \\
\text { inhibition }\end{array}$ & high inhibition & high inhibition & high inhibition \\
\hline 5. & $\begin{array}{c}006 \text { (Klebsiella } \\
\text { pneumonia) }\end{array}$ & Positive growth & $\begin{array}{c}\text { mild } \\
\text { inhibition }\end{array}$ & $\begin{array}{l}\text { moderate } \\
\text { inhibition }\end{array}$ & high inhibition & high inhibition \\
\hline 6. & $\begin{array}{c}010 \\
\text { (Pseudomonas } \\
\text { denitrificans) }\end{array}$ & Positive growth & $\begin{array}{c}\text { less } \\
\text { inhibition }\end{array}$ & mild inhibition & $\begin{array}{l}\text { moderate } \\
\text { inhibition }\end{array}$ & high inhibition \\
\hline
\end{tabular}




\subsection{Effects of Two Varieties of Oil on Wistar Rats Organs.}

Table 4: Rai Acid value, Iodine value, Saponification value and Unsaponifiable Matter of mustard (wild) and Rai (hybrid) rapeseeds oil.

\begin{tabular}{|c|c|c|c|c|}
\hline Name of oil & Acid value & Iodine value & Saponification value & $\begin{array}{c}\text { Unsaponification } \\
\text { value }\end{array}$ \\
\hline Mustard wild & $1.33 \pm .068$ & $111.055 \pm 1.82$ & $178.11 \pm 2.42$ & $1.395 \pm .037$ \\
\hline Rai hybr & $0.84 \pm .080$ & $85.67 \pm 5.49$ & $169.7 \pm .81$ & $1.00 \pm .12$ \\
\hline
\end{tabular}

\subsubsection{Determination of Acid Value of Rap Seeds Oil}

- In this data mustard wild and Rai hybrid shows acid value $1.33,0.84$. Here the acid value of mustard wild is greater compare to Rai hybrid. The standard error of mustard wild and Rai hybrid includes the value $0.68,0.080$ respectively that have been shown in the column.

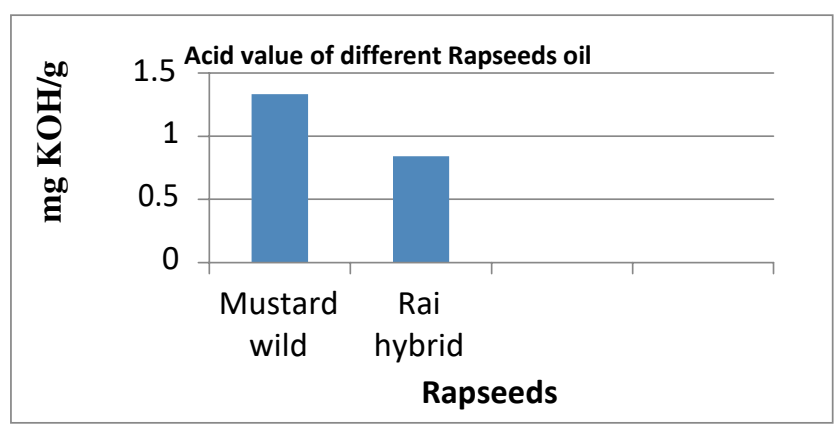

Fig 5: Graphical representation of Acid value of rapeseed oil.

\subsubsection{Determination of Saponification Value of} Rapeseeds Oil - In this data mustard wild and rai hybrid shows acid value 178.11, 169.7. Here the acid value of mustard wild is greater compare to rai hybrid. The standard error of mustard wild and rai hybrid includes the value $2.42,0.81$ respectively that have been shown in the column.

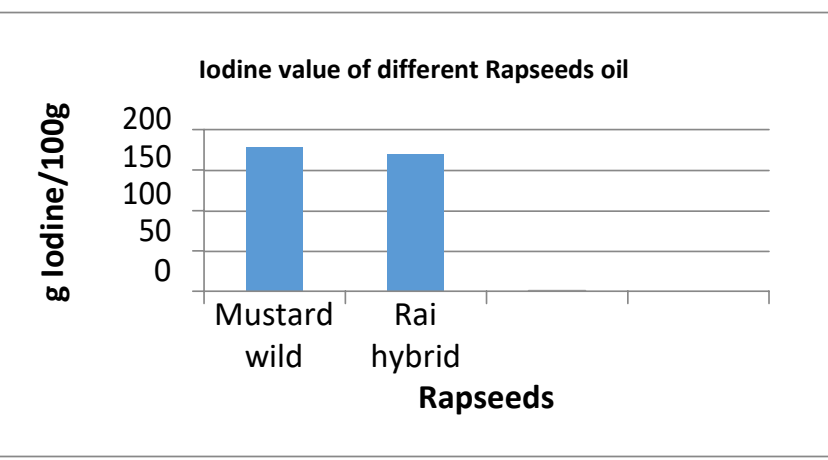

Fig 6: Graphical representation of Iodine value of rapeseed oil.

3.2.3 Body Weight Gain - The average weight body gain of the rats was measured for 6 weeks. The Table 5 illustrates the mean values of bodyweight gain of the rats fed diet with Mustard wild; Rai hybrid illustrates the graphical presentation of body weight gain of rats for the eight weeks. One group was considered as control rat which fed only normal diet. And another seven groups of rat induced the normal diet with $0.6 \mathrm{gm}$ Mustard wild, a normal diet with 0.6 gm Rai hybrid. The average body weight gain of rats was calculated into weekly and plotted on the graph weight gain vs. week.

Table 5: Body weight of different groups.

\begin{tabular}{|c|c|c|c|}
\hline Duration (week) & Group A (Control diet) & Group B Mustard (wild) & Group Rai (hybrid) \\
\hline 1week & $10.33 \pm 1.83$ & $8 \pm 0.55$ & $8.25 \pm 1.75$ \\
\hline 2week & $31.44 \pm 0.92$ & $24.05 \pm .81$ & $24.54 \pm 0.87$ \\
\hline 3week & $47.33 \pm 1.09$ & $37.95 \pm 1.84$ & $36.45 \pm 1.98$ \\
\hline 4week & $59.81 \pm .68$ & $45.2 \pm 0.44$ & $46.75 \pm 1.26$ \\
\hline 5week & $67.67 \pm 2.00$ & $53.1 \pm 0.76$ & $59.35 \pm 1.28$ \\
\hline 6week & $78.00 \pm 0.29$ & $61.25 \pm 1.65$ & $64.53 \pm 0.76$ \\
\hline 7week & $86.55 \pm .43$ & $70.42 \pm 0.23$ & $81 \pm 1.68$ \\
\hline 8week & $94.22 \pm 0.17$ & $77.33 \pm 0.87$ & $91.33 \pm 1.11$ \\
\hline
\end{tabular}

It was observed that the average weight of the rats in group A linearly increased. From $1^{\text {st }}$ to last weeks the point of Group A is showed weight gain linearly. At the last week $\left(8^{\text {th }}\right.$ week) group A showed the highest weight gain than the other two groups. Group B showed weight gain linearly from the 1 st to $3^{\text {rd }}$ week except the $4^{\text {th }}$ and $5^{\text {th }}$ week. In this point slightly prohibited the continuous weight gain of rats. Group B leading to the lowest weight gain compared to group A and C. Group $\mathrm{C}$ showed weight gain linearly from the $1^{\text {st }}$ to $4^{\text {th }}$ week except for the $5^{\text {th }}$ and $6^{\text {th }}$ week. In this point slightly prohibited the continuous weight gain of rats. 
Table 6: Food efficiency ratio.

\begin{tabular}{|l|c|c|c|c|c|}
\hline Groups & $\begin{array}{c}\text { Initial body } \\
\text { weight } \mathbf{( g )}\end{array}$ & $\begin{array}{c}\text { Final body } \\
\text { weight }(\mathbf{g})\end{array}$ & $\begin{array}{c}\text { Body weight gain } \\
\mathbf{( g )}\end{array}$ & Food Intake & Food efficiency ratio (FER) \\
\hline Group A & $89.33 \pm 3.79$ & $183.55 \pm 3.55$ & $94.22 \pm 0.14$ & $1045.48 \pm 2.79$ & $0.09 \pm 0.05$ \\
\hline Group B & $77.5 \pm 2.13$ & $165.25 \pm 2.32$ & $80.25 \pm 0.19$ & $1094.5 \pm 3.24$ & $0.07 \pm .05$ \\
\hline Group C & $86.75 \pm 4.495$ & $178.083 \pm 4.61$ & $91.33 \pm .12$ & $1064.89 \pm 2.61$ & $0.08 \pm .04$ \\
\hline
\end{tabular}

Rats fed for 8 weeks and Food Efficiency Ratio (FER) was measured. Group A fed normal diet, Group B for diet combined with Mustard (wild) oil and Group C for a diet with Rai (hybrid) oil. The table indicates that when rats were fed normal diet combine with Mustard (wild) and Rai (hybrid) oil, there is highly decrease of FER as compare to control Group A. The FER of Group B Mustard (hybrid) oil that is exhibited lower than Rai (hybrid) group.

3.2.4 Estimation of ALP in Rat Serum - ALP levels of group A includes the value $125.2 \mathrm{U} / \mathrm{L}$. whereas group B and group C include the value 201.96 and156.23 respectively compare with control group B and group $\mathrm{C}$ had increased ALP level. ALP level of group B value is the highest point compares to group C.

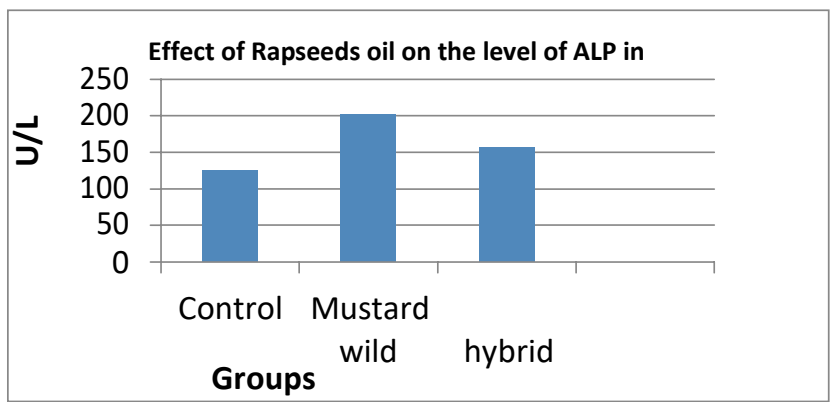

Fig 7: Graphical representation of rapeseed oil on the level of ALP activity in rats.

3.2.5 Estimation of CK-MB Group A - Group A rat of CK-MB include the value 33.72 and 32.24 respectively compare with control group B and group $\mathrm{C}$ had increased CK-MB level. CK-MB level of group, B value is the highest point compare to group C.includes the value $31.36 \mathrm{U} / \mathrm{L}$. whereas group $\mathrm{B}$ and group $\mathrm{C}$

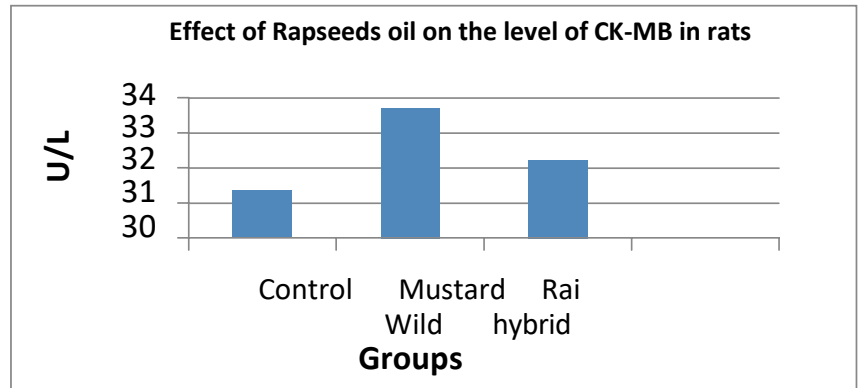

Fig 8: Graphical representation of rapeseed oil on the level of CK-MB activity in rats.
3.2.6 Estimation of SGPT (ALT) in rat serum group A - Group A rat of SGPT (ALT) includes the value $35.06 \mathrm{U} / \mathrm{L}$. whereas group B and group $\mathrm{C}$ include the value 42.345 and 39.93 respectively compare with control group B and group C had increased SGPT(ALT) level. SGPT (ALT) level of group B value is the highest point compare to group $\mathrm{C}$.

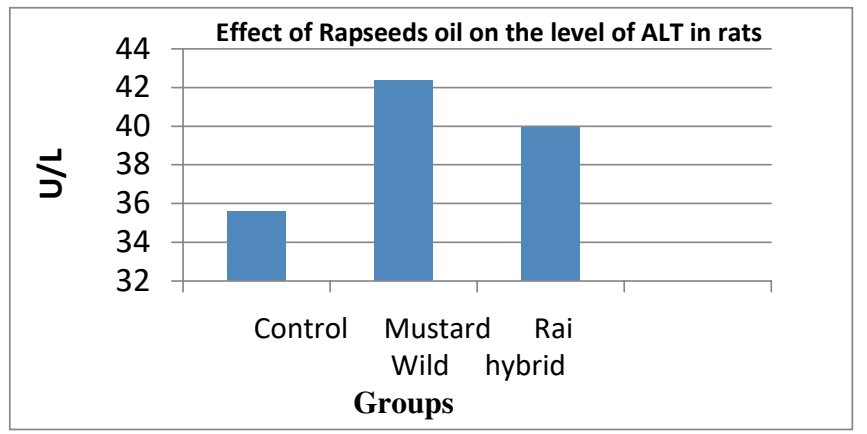

Fig 9: Graphical representation of rapeseed oil on the level ALT of activity in rats.

3.2.7 Estimation of SGOT (AST) in Rat Group A Group A rat of SGOT (AST) includes the value 35.06 $\mathrm{U} / \mathrm{L}$. whereas group $\mathrm{B}$ and group $\mathrm{C}$ include the value 42.345 and 39.93 respectively compare with control group B and group C had increased SGOT (AST) level. SGOT (AST) level of group B value is the highest point compare to group $\mathrm{C}$.

\section{DISCUSSIONS}

Rapeseed oil is grown as an edible oilseed crop in Bangladesh, India and Pakistan. Rapeseed oil has a pungent smell and a sharp taste. The edible rapeseed oil contains the lowest amount of saturated fatty acids as compared to other vegetable oils. It contains nutritionally desired oleic acid, which gives stability to the oil, along with two essential fatty acids, linoleic and linolenic. However, in addition, it is characterized by high levels of monounsaturated fatty acids (62\%) and significant levels of polyunsaturated fatty acids $32 \%$, and it contains very little saturated acids 6\% (Alander et al., 2007). There are basically four types of rapeseed oil namely Mustard (Wild), Mustard (hybrid), Rai (Wild) and Rai (hybrid) were used to finding out the activity against microorganisms. 


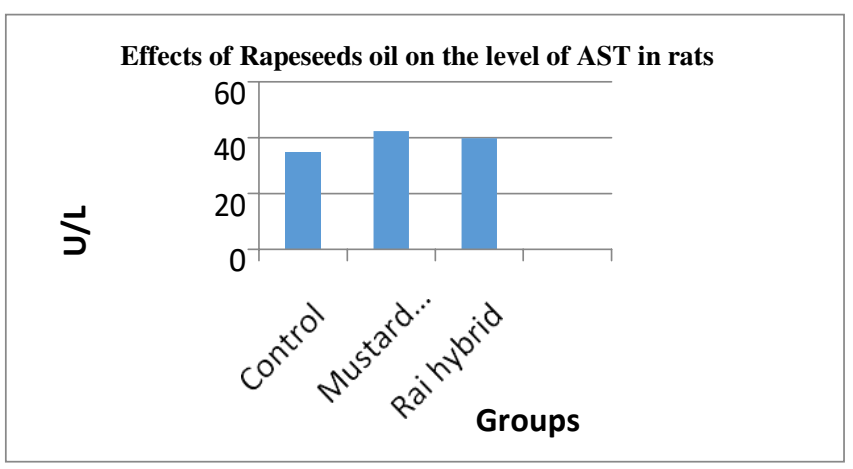

Fig 10: Graphical representation of rapeseed oil on the level of AST activity in rats.

We observed that all types of tested oil possessed toxic effects against bacteria which are shown in Fig 1-4 and Table 1-6 This result might be due to rapeseeds oil contains erucic acid, a 22 carbon long-chain monounsaturated fatty acid, which is harmful to health as well as living organisms. It also contains high amounts of erucic acid, which is nutritionally undesired. There is a report that erucic acid-rich oil may cause cardiac lipidosis by the accumulation of substantial fat in the heart muscle (Kramer et al., 1992). After examination of antimicrobial activities of oil, adult male Wistar rats have been treated with the control diet, Mustard (wild) and Rai (hybrid) oils at 8 weeks (56 days). Then the physiological effects of oil were tested.

In this study, we observed that the average weight of the rats in the control group increased linearly from the first week to last week at each time point. Mustard (hybrid) oil group showed weight gain linearly from 1st to $4^{\text {th }}$ week, $7^{\text {th }}$ week and $8^{\text {th }}$ week but except the point $5^{\text {th }}$ and $6^{\text {th }}$ weeks. It reflects that the reduction rate of body weight of rats is highest in mustard Wild oiltreated group compared to control and rai hybrid groups. Mustard (Wild) oil group has growth retarding activity compared to both the control group and Rai (hybrid) group caused by erucic acid. Several mechanisms may be responsible for diminishing weight by mustard (Wild) oil. It has been shown that high body weight gain for rats fed diet containing low erucic acid rape oil than the high (Badawy, 1994, Renner, 1979). Because of these injuries rats tend to consume a lower amount of diet, leading to ultimate weight loss or it may also happen that though rats ate diet, but due to these metabolic disorders, they could not able to digest it. So it could be decided that reason for lower weight gain is the development of metabolic disorders in Mustard oil (erucic acid) induced rats. Rai (hybrid) group $\mathrm{C}$ showed weight gain linearly without 6 th week. This may be due to fewer intakes of foods because of the physiological condition of rats. Rats fed for 8 weeks and FER was measured and results summarized in Table 6.

We observed that food intake was lowest in the control group but FER is highest in controlled animals, whereas rats fed normal diet combined with Mustard (Wild) and Rai (hybrid) decrease FER as compared to the control group. This may be due to the fact that they are unable to digest it due to metabolic disturbance caused by erucic acid which is toxic and lower the FER by creating metabolic problem in rats. Our results indicate that control diet group improved the digestion power of rats. Alkaline phosphatase is an enzyme found throughout the body. It is a hydrolyzing enzyme responsible for removing phosphate groups from many types of molecules including nucleotides, proteins, and alkaloids. Diseases that damage and destroy the cells of organs lead to the release of alkaline phosphatase into the blood, which raises the blood level of alkaline phosphatase.

Large scale infections can also increase the enzyme. Thereby, we checked the level of ALP in rat serum of experimental groups. Compared with control group (A), Mustard (Wild) Group B and Rai (hybrid) Group C had increased ALP levels shown in Fig 4. Usage of a higher dosage of erucic acid (38.2\%) in Mustard oil group is responsible for inflammation. It is also found elevated ALP level in erucic acid-induced rats like present study (Badawy, 1994). ALP levels of group B Mustard (Wild) value is higher ALP compared to the control and Rai (hybrid) oils. CK-MB is a form of the enzyme that is found mainly in the heart. It helps cells to perform their normal functions but it rises in blood level when specifically heart cells are injured. A high CK-MB level suggests that there is disease or damage to the heart muscle specifically (Panteghini, 1998).

The CK-MB level in rat serum was estimated after 8 weeks. On compared with the control group (A), Mustard (Wild) Group B and Rai (hybrid) Group C had increased CK-MB levels shown in Fig 5. The increase in CK-MB level of Mustard (hybrid) oil group may indicate damage to heart muscle specifically. It is reported that erucic acid is poorly oxidized by the mitochondrial beta-oxidation system, especially by the myocardial cells, which results in an accumulation of erucic acid, producing myocardial lipidosis which has been reported to reduce the contractile force of the heart (Mori, 1998). Control group has the lowest CK-MB level compare to other rapeseed oil groups. ALT is also known by the name of SGPT. It is normally concentrated in the liver. 
The moment there is an injury in the liver, it is released into the bloodstream. Therefore, the ALT level in rat serum was examined in rats. On compared with control group (A), Mustard (Wild) Group B and Rai (hybrid) Group C had increased ALT levels shown in Fig 6. The ALT levels of group B mustard (Wild) value are the highest compared to Rai (hybrid) oil. The elevation of ALT indicates injury of liver function in rats fed Mustard oil. The enzyme AST is also known by the name of SGOT is a more specific indicator that primarily aids to the diagnosis of liver disease but also aid to the diagnosis of heart injury. So, we checked the AST level in rat serum. On compared with the control group (A), Mustard (Wild) Group B and Rai (hybrid) Group C had increased AST levels shown in Fig 7 AST levels of group B mustard (Wild) value is a higher compared to Rai (hybrid) oils. This elevation of AST might be due to higher dose of erucic acid in Mustard wild groups because erucic acid is responsible for inflammation. It might due to its high erucic acid content.

\section{CONCLUSION}

Rapeseed is an important oil crop in Bangladesh which can contribute to a large extent in the national economy. The people of Bangladesh and many other countries consume this edible oil. Especially in the rural area of our country use more this edible oil as a chief source of nutritionally required fatty acids in the human diet. Rapeseed oil is one of the oldest vegetable oils that contain erucic acid which is harmful to health. Our study investigated the antimicrobial activity of rapeseeds oil in addition to the physiological effects of two varieties of oil namely Mustard (wild) and Rai (hybrid) on Wistar rat organs. Results showed that erucic acid of Mustard (wild) and Rai (hybrid) causes the weight loss of rat to compare to control diet groups of rats. In addition rapeseeds, oil of Mustard (wild) and Rai (hybrid) reduced Food Efficiency Ratio (FER) compare to control diet groups. It also elevated blood serum enzymes SGOT, CK-MB, SGPT, ALP level. Mustard (wild) was shown more effective compare to Rai (Hybrid) rapeseed oil. Both types of oil contain a high amount of erucic acid that has adverse effects on cardiac and hepatic enzymes. So human should not be consumed rapeseed oil an excess amount that contains high erucic acid but consumes only that rapeseed oil that contains a low amount of erucic acid that has no adverse effect on health.

\section{ACKNOWLEDGEMENTS}

This research was financially supported with proper guidance and help for data analysis in the Dept. of Biotechnology and Genetic Engineering, Islamic University, Bangladesh. Heartiest thanks to the coauthors for helping us to conduct the research work.

\section{CONFLICTS OF INTEREST}

The author (s) declared no potential conflicts of the interest with respect to the research work.

\section{REFERNCES}

1. Alander J, Andersson A, Bagge C, Bringsarve K, Hjorth M, Johansson M, Granroth, B, Norberg S, Pedersen M, Persson M, Wennermark B, and Wennermark M. (2007) Raw materials. In: Lidefelt, J. (Ed.), Handbook of Vegetable Oils and Fats. $2^{\text {nd }}$ ed. Alfaprint, Sweden.

2. Badawy, I. H., Atta, B., and Ahmed, W. M. (1994) Biochemical and toxicological studies on the effect of high and low erucic acid rapeseed oil on rats. Food/Nahrung, 38(4), 402-411.

3. Bhuiyan, M. S., Mondol, M. R. I., Rahaman, M. A., Alam, M. S., and Faisal, A. H. M. A. (2008) Yield and yield attributes of rapeseed as influenced by the date of planting. International J. for Sustainable Crop Production, 3(3), 25-29.

4. Cao, X., Tsukamoto, T., Seki, T., and Tanaka, H. (2008) Vinyl-2, 6-dimethoxyphenol (Canolol) suppresses oxidative stress and gastric carcinogenesis in Helicobacter pylori infected carcinogen-treated Mongolian gerbils. Int. J. Cancer., 122, 1445-1454.

5. Gunstone F. (2011) editor. Vegetable oils in food technology: Composition, properties, and uses. Blackwell Publishing.

6. Kramer, J. K. G., Sauer, F. D., Wolynetz, M. S., Farnworth, E. R., and Johnston, K. M. (1992). Effects of dietary saturated fat on erucic acidinduced myocardial lipidosis in rats. Lipids, 27(8), 619-623.

7. Lomascolo A., Uzan-Boukhris E., Sigoillot J.C., and Fine F. (2012) Rapeseed and sunflower meal: a review on biotechnology status and challenges. App. Microbiol. Biotechnol., 95, 1105-1114.

8. Martin Hernandez C., Benet S. and Obert L. (2008) Determination of proteins in refined and non-refined oils. J. Agric. Food. Chem., 56(12), 4348.

9. McKevith, B. (2005) Nutritional aspects of oilseeds. Nutrition Bulletin, 30 (1), 13-26. 
10. Mori, H., Tanaka, T., and Hirono, I. (1998) Toxicants in food: Naturally occurring. Nutrition and Chemical Toxicity, 1-27.

11. Mosyakin, S. L., \& Robertson, K. R. (1996) New infrageneric taxa and combinations in Amaranthus (Amaranthaceae). Finnish Zoological and Botanical Publishing Board. Annales Botanici Fennici, pp. 275-281.

12. O'brien, R. D. (2008) Fats and oils: formulating and processing for applications. CRC press.

13. Panteghini, M. (1998) Diagnostic application of CK-MB mass determination. Clinica Chimica Acta, 272(1), 23-31.

14. Renner, R., Innis, S. M., and Clandinin, M. T. (1979) Effects of high and low erucic acid rapeseed oils on energy metabolism and mitochondrial function of the chick. The $J$. of nutrition, 109(3), 378-387.

15. Sarker MKD, Ahammed T, Sahabuddin M, Haque A, Hossain MR, Mosaib MG, Islam MR, Mondol GC, and Alam MF. (2019) Antibiotic Resistance Analysis of Vibrio spp Isolated from Different Types of Water Sources of Bangladesh and Their Characterization. Eur. J. Med. Health Sci., 1(4), 19-29.

https://doi.org/10.34104/ejmhs.01929

16. Siger A, Gawrysiak-Witulska $M$, and Bartkowiak-Broda I. (2017) Antioxidant (Tocopherol and Canolol) content in rapeseed oil obtained from roasted yellow seeded
Brassica napus. J. of the American Oil Chemists' Society, 94(1): 37-46. https://doi.org/10.1007/s11746-016-2921-7

17. Thiyam, U., Stockman, H., Zum Felde, T., Schwarz, K. (2006) Antioxidative effect of the main sinapic acid derivatives from rapeseed and mustard oil by-products. Eur. J. Lipid Sci. Technol., 108, 239-248.

18. Vuorela, S., Kreander, K., Karonen, M., and Nieminen, R. (2005) Preclinical evaluation of rapeseed, raspberry, and pine bark phenolics for health-related effects. J. Agric. Food Chem., 53, 5922-5931.

19. Wakamatsu, D., Morimura, S., Sawa, T., and Kida, K. (2005) Isolation, identification, and structure of a potent alkyl peroxyl radical scavenger in crude canola oil, Canolol. Biosci. Biotechnol. Biochem., 69, 1568-1574.

20. Walter, U., Beyer, M., Klein, J., and Rehm, H. J. (1991) Degradation of pyrene by Rhodococcus sp. UW1. Applied Microbiology and Biotechnology, 34(5), 671-676.

21. Weber, T., Hanisch, E., Baum, R. P., and Seufert, R. M. (1998) Late results of heterotopic autotransplantation of splenic tissue into the greater omentum. World J. of surgery, 22(8), 883-889.

22. Zhang S. B., Wang Z., and Xu S. Y. (2007) Optimization of the Aqueous Enzymatic Extraction of Rapeseed Oil and Protein Hydrolysates. J. Amer Oil Chem Soc. 84, 97-105

Citation: Sharif IH, Tamanna S, Mosaib MG, Tamanna N, Haque MA, Jamal MAHM, and Uddin ME. (2019). Assessment and biomonitoring of the effect of rapeseeds oil on wister rat organs. Am. J. Pure Appl. Sci., 1(4), 20-29. https://doi.org/10.34104/ajpab.019.0192029 (c) (9) 